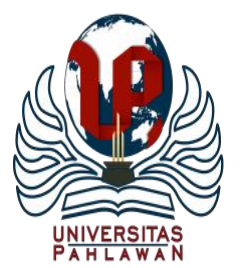

Jurnal Abdidas Volume 2 Nomor 3 Tahun 2021 Halaman 558-565

JURNAL ABDIDAS

http://abdidas.org/index.php/abdidas

\title{
Pendampingan Pengolahan Limbah Konveksi Menjadi Barang Dengan Nilai Jual Tinggi
}

\author{
Dwi Ardiyanti ${ }^{1 \bowtie}$, Inda Aini Sichah ${ }^{2}$, Alfidayati Hasna ${ }^{3}$, Cindy Oktaviana Putri ${ }^{4}$, Nurmalasari Mulia \\ Putri $^{5}$, Adinda Muhariani ${ }^{6}$ \\ Hubungan Internasional, Universitas Potensi Utama, Indonesia ${ }^{1,2,3,4,5,6}$ \\ E-mail: $\underline{\text { ardiyanti.1987@gmail.com }}{ }^{1}$
}

\begin{abstract}
Abstrak
Tailor merupakan tempat produksi pakaian yang menggunakan bahan dasar kain. Dalam pembuatan pakaian, kain yang digunakan akan menyisakan kain perca. Kain perca merupakan golongan sampah anorganik yang tidak dapat diurai. Namun, dalam pendampingan ini akan dibahas tentang pengelolaan kain perca sebagai limbah konveksi ini menjadi produk berdaya jual lebih tinggi. Metode yang digunakan adalah pendampingan dan sosialisasi program selama sebulan di lapangan. Permasalahan yang diangkat dalam penelitian ini adalah bagaimana sisa kain yang biasanya menjadi limbah terbuang dapat dimanfaatkan untuk memperoleh barang dengan nilai jual yang lebih tinggi, misalnya hiasan pot bunga, ikat rambut dan konektor masker. Sejauh ini, tidak banyak yang dilakukan untuk mengelola limbah kain perca ini. Hasilnya, kegiatan pengabdian kepada masyarakat ini dapat bermanfaat bagi pekerja tailor, yaitu selain mengandalkan gaji sebagai penjahit tailor di Universitas Darussalam Gontor, mereka bisa membawa pulang limbah kain perca ke rumah dan mengolahnya kembali menjadi barang-barang yang juga banyak dibutuhkan.
\end{abstract}

Kata kunci: limbah konveksi, kain perca, pengelolaan, daya jual

\section{Abstract}

Tailor is a place for clothing production that uses fabric as basic materials. In making clothes, the fabric used will leave patchwork. Patchwork is a group of inorganic waste that cannot be decomposed. However, in this assistance, we will discuss the management of patchwork as convection waste into products with higher selling power. The method used is assistance for a month in the field and field research. The problem raised in this study is how the rest of the cloth which is usually wasted waste can be used to obtain goods with higher selling values, such as flower pot decorations, hair ties and mask connectors. So far, not much has been done to manage this patchwork waste. As a result, this community service activity can be beneficial for tailor workers, namely apart from relying on salaries as tailors at UNIDA Gontor, at home they can bring home waste patchwork and reprocess it into items that are also much needed.

Keywords: convection waste, patchwork, management, selling power

Copyright (c) 2021 Dwi Ardiyanti, Inda Aini Sichah, Alfidayati Hasna, Cindy Oktaviana Putri, Nurmalasari Mulia Putri, Adinda Muhariani

$\triangle$ Corresponding author

Address : Universitas Darussalam Gontor

Email : ardiyanti.1987@gmail.com

DOI : https://doi.org/10.31004/abdidas.v2i3.315

ISSN 2721- 9224 (Media Cetak)

ISSN 2721- 9216 (Media Online) 
559 Pendampingan Pengolahan Limbah Konveksi Di Malika Tailor UNIDA Putri - Dwi Ardiyanti, Inda Aini Sichah, Alfidayati Hasna, Cindy Oktaviana Putri, Nurmalasari Mulia Putri, Adinda Muhariani DOI: https://doi.org/10.31004/abdidas.v2i3.315

\section{PENDAHULUAN}

Masalah sampah di dunia merupakan masalah besar yang masih butuh penanganan dan pengelolaan serius dari setiap warga dunia. Salah satu cara dalam mengelola sampah adalah mengolah kembali limbah yang masih bisa dimanfaatkan. Hal ini perlu dilakukan demi hunian bagi generasi nantinya yang lebih baik. Sampah dibagi menjadi dua, yaitu sampah organik dan sampah aroganik. Untuk sampah organik, pemanfaatan yang bisa dilakukan adalah dengan mengolah kembali menjadi pupuk maupun pakan ternak. Sedangkan limbah anorganik menjadi tugas bagi kita semua untuk mengelolanya (Susilo \& Karya, 2012).

Salah satunya adalah limbah kain yang menduduki piosisi nomor 4 terbanyak di dunia, terbanyak yakni $6,36 \%$ secara berat dan $5,1 \%$ secara volume, dengan jumlah sampah harian di Bandung yang mencapai kurang lebih 1000 ton per hari dengan peningkatan sekitar 3\% sampai $5 \%$ per tahunnya (Susilo \& Karya, 2012). Dalam tulisan (Susilo \& Karya, 2012) tersebut juga membahas bagaimana keresahan tentang semakin banyaknya limbah kain yang ada dan kemudian bisa dimanfaatkan kembali. Menurut penelitian yang dilakukan oleh Environmental Protection Agency, setiap harinya limbah padat mencapai terdapat 4.3 pon, meningkat 2.7 pon di tahun 1960 (Hawley, 2006).

Dalam tulisan ini menggunakan kain sisa atau dengan istilah reuse (penggunaan kembali). Penggunaan tekstil berarti berbagai cara yang dilakukan untuk menggunakan kembali dan memperpanjang penggunaan produk tekstil dengan cara mentransfer ke pengguna yang baru ((Sandin \& Peters, 2018)(Ekström \& Salomonson, 2014)).

Tailor UNIDA Putri Kampus Reguler merupakan salah satu bentuk industri mitra Unit Usaha UNIDA (U3) yang bergerak dalam bidang konveksi yang memproduksi berbagai kebutuhan pakaian dalam jumlah yang cukup besar. Mitra Tailor UNIDA Putri memproduksi seragam, kerudung, mukena, dan menerima perbaikan atau pemotongan baju. Target hasil produksi hanya ditujukan kepada lingkungan internal kampus yaitu para mahasiswi UNIDA Putri Kampus Reguler.

Lokasi Tailor UNIDA Putri terletak pada lokasi yang strategis, karena lokasi tersebut merupakan jalan favorit mahasiswi sebagai jalan pintas yang menghubungkan antara satu gedung asrama satu dengan gedung asrama yang lainnya dan juga dari satu unit usaha ke unit usaha lainnya seperti unit usaha mie ayam dan Kopda. Dengan begitu, maka kebersihan Tailor UNIDA Putri Kampus Reguler perlu diperhatikan.

Dikarenakan tailor yang memproduksi seragam dalam jumlah yang banyak, menyebabkan adanya limbah kain perca yang banyak pula. Limbah kain perca yang sedemikian banyak, biasanya hanya cukup dibuang begitu saja oleh pekerja pemotong kainnya. Limbah kain merupakan limbah padat anorganik yang tidak dapat membusuk karena tidak adanya aktivitas mikroorganiasme pengurai. Oleh karenanya, limbah padat jenis ini sebaiknya didaur ulang agar dapat dimanfaatkan kembali. Memanfaatkan limbah kain perca menjadi sesuatu yang bisa digunakan kembali akan memberi dampak yang 
560 Pendampingan Pengolahan Limbah Konveksi Di Malika Tailor UNIDA Putri - Dwi Ardiyanti, Inda Aini Sichah, Alfidayati Hasna, Cindy Oktaviana Putri, Nurmalasari Mulia Putri, Adinda Muhariani DOI: https://doi.org/10.31004/abdidas.v2i3.315

sangat baik bagi bumi yaitu mengurangi efek pemanasan global (Purwasih et al., 2020).

Ada banyak cara untuk menanggulangi atau mengolah limbah tersebut, seperti dengan cara pemupukan dan pengomposan untuk limbah organik, serta pembakaran untuk limbah anorganik. Namun pembakaran untuk limbah anorganik memiliki efek samping seperti polusi yang tidak baik untuk lingkungan. Polusi tersebut menimbulkan gas beracun seperti karbon manosida, ammonia, $\mathrm{HCN}$, dan lain sebagainya (Purwasih et al., 2020).

Dari latar belakang tersebut, penulis memberikan penawaran solusi berupa pengolahan limbah kain perca yang diolah kembali menjadi produk yang memiliki nilai ekonomis yang lebih tinggi dengan cara pengolahan limbah kain menjadi barang yang lebih bermanfaat, seperti pot bunga dari limbah kain, ikat rambut dan connector masker. Selain ramah lingkungan, hal tersebut dapat menambah income untuk para pekerja di Tailor UNIDA Putri Regular.

\section{METODE}

Metode pelaksanaan yang digunakan dalam kegiatan KKN adalah berupa metode pelaksanaan pendekatan sosial. Pendekatan sosial merupakan peleburan atau pengintegrasian diri bagi para pelaksana utama KKN yaitu para peserta KKN dalam masyarakat supaya dapat diterima dan berperan serta dalam berbagai kegiatan masyarakat. Peserta KKN merupakan subjek dari kegiatan KKN ini yaitu sebagai pendamping dan pengolah limbah kain perca yang diproduksi oleh Tailor UNIDA Putri. Sedangkan, Tailor UNIDA
Putri merupakan objek dari kegiatan masyarakat ini, yaitu sebagai mitra yang menyediakan bahan baku, berupa kain perca untuk dibuat pot. Serta bekerja sama dengan divisi peduli lingkungan DEMA yang akan menjadi konsumen dari hasil pot yang dihasilkan.

Berikut ini adalah jadwal kegiatan yang telah dilaksanakan.

$\begin{array}{lll}\text { Hari/tgl } & : & \text { April -Mei } 2021 \\ \text { Tempat } & : & \text { Lingkungan kampus UNIDA } \\ & \text { Gontor Putri 1, Mantingan } \\ \text { Sasaran } & : \text { Malika Tailor UNIDA Gontor } \\ & & \text { (Putri 1) }\end{array}$

Alur kegiatan :

\section{Tahap 1. Pendekatan dan Sosialisasi kepada Para Pekerja Tailor UNIDA Gontor (Putri 1)}

Pendekatan dan sosialisasi ini akan dilakukan dengan cara mendatangi mitra tersebut dan mengajak para pekerja tailor untuk bersamasama mengurangi limbah konveksi dengan cara mengolahnya kembali menjadi barang yang masih dapat digunakan, seperti hiasan pot, ikat rambut, konektor masker dan masih banyak yang lainnya.

Dalam tahapan ini, target yang ingin dicapai adalah kemauan para pekerja tailor untuk mendapatkan pendampingan. Target selanjutnya adalah pekerja tailor mau meluangkan waktunya untuk dilakukan sosialisasi kegiatan.

\section{Tahap 2. Pengumpulan dan Pemisahan Bahan}

Bahan akan dikumpulkan dari tailor dan dalam tahap ini akan dilakukan pemisahan antara kain perca ukuran besar dan kain perca dalam ukuran kecil. Masalah dalam tahapan ini adalah 
561 Pendampingan Pengolahan Limbah Konveksi Di Malika Tailor UNIDA Putri - Dwi Ardiyanti, Inda Aini Sichah, Alfidayati Hasna, Cindy Oktaviana Putri, Nurmalasari Mulia Putri, Adinda Muhariani DOI: https://doi.org/10.31004/abdidas.v2i3.315

adanya kesamaan warna dan jenis semua kain. Karena tailor ini berfokus pada pembuatan seragam santri yang sewarna.

Target dalam tahapan ini tercapai, yaitu mendapatkan bahan yang dibutuhkan untuk membuat hiasan pot, ikat rambut, konektor masker. Para pelaksana kegiatan pendampingan juga membantu merapikan ruangan.

Tahap 3. Pemberian Contoh dan Pendampingan

Peserta yang merupakan subjek dari pengabdian kepada masyarakat ini akan memberikan contoh dan pendampingan kepada para pekerja tentang bagaimana mengolah limbah konveksi tersebut menjadi barang-barang yang telah disebutkan di atas. Dalam tahapan ini target tercapai dengan baik dan mitra (Malika Tailor) juga bersedia mengikuti kegiatan hingga akhir.

\section{HASIL DAN PEMBAHASAN}

Tailor UNIDA Putri sebagai mitra kami belum mengolah limbah kain dengan benar. Dengan adanya kegiatan pengabdian kepada masyarakat ini, pihak mitra merasa sangat terbantu dalam hal pengolahan limbah kain perca.

Tabel 1. Pelaksanaan Kegiatan

\begin{tabular}{|c|c|c|c|c|}
\hline NO & Bentuk Kegiatan & $\begin{array}{c}\text { Waktu Pelaksanaan } \\
\text { Kegiatan }\end{array}$ & Sasaran Kegiatan & $\begin{array}{c}\text { Hambatan } \\
\text { Program }\end{array}$ \\
\hline 1 & $\begin{array}{l}\text { 1. Melakukan survei ke mitra } \\
\text { Tailor UNIDA Putri pertama } \\
\text { kali } \\
\text { 2. Penyusunan Proposal KKN } \\
\text { Tematik }\end{array}$ & 4 April 2021 & $\begin{array}{l}\text { 1. Melihat secara } \\
\text { umum proses } \\
\text { produksi di Malika } \\
\text { Tailor } \\
\text { 2. Menyusun program } \\
\text { kerja kelompok dan } \\
\text { proposal KKN }\end{array}$ & $\begin{array}{l}\text { Belum dapat } \\
\text { menyusun proposal } \\
\text { KKN dengan baik } \\
\text { dan benar }\end{array}$ \\
\hline 2 & $\begin{array}{l}\text { 1. Pengajuan proposal kepada } \\
\text { Dosen Pembimbing Lapangan } \\
\text { 2. Pengumpulan proposal }\end{array}$ & 5 April 2021 & $\begin{array}{l}\text { 1. Mengajukan } \\
\text { proposal KKN dan } \\
\text { permintaan } \\
\text { persetujuan kepada } \\
\text { Dosen Pembimbing } \\
\text { Lapangan } \\
\text { 2. Mengumpulkan } \\
\text { proposal kepada } \\
\text { Koordinator Wilayah } \\
\text { dan website (soft dan } \\
\text { hard file) }\end{array}$ & \\
\hline 3 & $\begin{array}{l}\text { Percobaan pertama produk dari } \\
\text { limbah konveksi }\end{array}$ & 6 April 2021 & $\begin{array}{l}\text { Pembuatan pot bunga } \\
\text { dari kain perca }\end{array}$ & $\begin{array}{lr}\text { Terdapat } & \text { kesalahan } \\
\text { dalam } & \text { proses } \\
\text { pembuatan } & \text { pot } \\
\text { bunga } & \end{array}$ \\
\hline 4 & $\begin{array}{l}\text { 1. Pembukaan KKN Tematik } \\
\text { UNIDA Kampus Putri } \\
\text { 2. Perpindahan kamar peserta KKN } \\
\text { Tematik UNIDA Putri } \\
\end{array}$ & 7 April 2021 & $\begin{array}{l}\text { Pembersihan umum } \\
\text { asrama }\end{array}$ & \\
\hline 5 & $\begin{array}{l}\text { 1. Kunjungan ke mitra } \\
\text { 2. Pembuatan produk }\end{array}$ & 8 April 2021 & $\begin{array}{l}\text { 1. Pengambilan kain } \\
\text { perca dari tailor }\end{array}$ & \\
\hline
\end{tabular}


562 Pendampingan Pengolahan Limbah Konveksi Di Malika Tailor UNIDA Putri - Dwi Ardiyanti, Inda Aini Sichah, Alfidayati Hasna, Cindy Oktaviana Putri, Nurmalasari Mulia Putri, Adinda Muhariani DOI: https://doi.org/10.31004/abdidas.v2i3.315

\begin{tabular}{|c|c|c|c|c|}
\hline & & & $\begin{array}{lr}\text { 2. Pembuatan } & \text { pot } \\
\text { bunga } & \text { dengan } \\
\text { limbah } & \text { konveksi } \\
\text { berupa kain perca }\end{array}$ & \\
\hline 6 & Revisi proposal KKN Tematik & 9 April 2021 & $\begin{array}{l}\text { Pengesahan proposal } \\
\text { oleh Dosen Pembimbing } \\
\text { Lapangan }\end{array}$ & \\
\hline 7 & $\begin{array}{llr}\text { Pengajuan } & \text { proposal } & \text { setelah revisi } \\
\text { kepada } & \text { Dosen } & \text { Pembimbing } \\
\text { Lapangan } & & \\
& & \end{array}$ & 10 April 2021 & 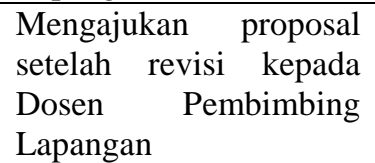 & \\
\hline 8 & $\begin{array}{l}\text { 1. Melakukan survey ke staf } \\
\text { penanggungjawab Malika Tailor } \\
\text { 2. Pengambilan bahan dari tailor }\end{array}$ & 11 April 2021 & $\begin{array}{l}\text { Konsultasi kepada staf } \\
\text { penanggung jawab } \\
\text { tailor }\end{array}$ & $\begin{array}{l}\text { Belum } \\
\text { terlaksananya } \\
\text { sosialisasi mengenai } \\
\text { pemanfaatan karena } \\
\text { hanya ada } 1 \text { pekerja } \\
\text { masuk }\end{array}$ \\
\hline 9 & $\begin{array}{l}\text { 1. Belanja anggaran peralatan } \\
\text { praktik } \\
\text { 2. Penyusunan Laporan Pekanan } \\
\text { KKN Tematik }\end{array}$ & 12 April 2021 & $\begin{array}{l}\text { 1. } \begin{array}{l}\text { Melengkapi } \\
\text { peralatan dan bahan } \\
\text { percobaan seperti } \\
\text { lem tembak, } \\
\text { kancing, benang, } \\
\text { jarum, pot, dsb. } \\
\text { 2. Pembuatan sampel } \\
\text { pengolahan limbah } \\
\text { konveksi }\end{array} \\
\end{array}$ & \\
\hline 10 & Pembuatan produk & 13 April 2021 & $\begin{array}{l}\text { 1. Percobaan } \\
\text { pembuatan } \\
\text { connector masker, } \\
\text { ikat rambut, dan } \\
\text { hiasan pot dari kain } \\
\text { perca } \\
\text { 2. Pembuatan poster } \\
\text { mengenai } \\
\text { pengolahan limbah } \\
\text { kain }\end{array}$ & \\
\hline 11 & Membuat soal pretest & 15 April 2021 & $\begin{array}{l}\text { Membagikan } r \\
\text { pretest ke para pekerja } \\
\text { mitra Tailor } \\
\text { Putri }\end{array}$ & $\begin{array}{l}\text { Pekerja tailor tidak } \\
\text { memiliki waktu } \\
\text { luang yang cukup } \\
\text { untuk menjawab } \\
\text { soal pretest }\end{array}$ \\
\hline 12 & Membuat poster & 16 April 2021 & $\begin{array}{lrr}\text { Untuk } & \text { memperbarui } \\
\text { poster } & \text { yang } & \text { akan } \\
\text { ditempel } & \text { di } & \text { Mitra } \\
\text { UNIDA Tailor } & \\
\end{array}$ & \\
\hline 13. & Sosialisasi pemanfaatan limbah kain & 17 April 2021 & $\begin{array}{ll}\text { 1. } & \text { Penempelan poster } \\
\text { 2. } & \text { Sosialisasi } \\
\text { pemanfaatan limbah } \\
\text { kain menjadi barang } \\
\text { yang lebih bernilai }\end{array}$ & \\
\hline 14 & Pengadaan post-test & 18 April 2021 & $\begin{array}{l}\text { Membagikan soal post- } \\
\text { test kepada para pekerja } \\
\text { mitra Tailor UNIDA }\end{array}$ & $\begin{array}{lr}\text { Tidak } & \text { semua } \\
\text { pekerja datang } \\
\text { ketika diadakannya } \\
\text { post-test }\end{array}$ \\
\hline 15 & $\begin{array}{lll}\begin{array}{l}\text { Pembuatan } \\
\text { dokumentasi }\end{array} & \text { laporan } & \text { video }\end{array}$ & 19 April 2021 & $\begin{array}{l}\text { Mendokumentasikan } \\
\text { kegiatan kelompok } 59 \\
\text { dalam bentuk video dan }\end{array}$ & \\
\hline
\end{tabular}


563 Pendampingan Pengolahan Limbah Konveksi Di Malika Tailor UNIDA Putri - Dwi Ardiyanti, Inda Aini Sichah, Alfidayati Hasna, Cindy Oktaviana Putri, Nurmalasari Mulia Putri, Adinda Muhariani

DOI: https://doi.org/10.31004/abdidas.v2i3.315

\begin{tabular}{|l|l|l|l|l|}
\hline & & & $\begin{array}{l}\text { foto selama pekan kedua } \\
\text { Kuliah Kerja Nyata }\end{array}$ & \\
\hline 16 & Penyusunan laporan pekanan & 20 April 2021 & $\begin{array}{l}\text { Menyusun laporan akhir } \\
\text { untuk pekan kedua } \\
\text { Kuliah Kerja Nyata }\end{array}$ & \\
\hline
\end{tabular}

Evaluasi kegiatan ini dengan menggunakan metode pretest dan post-test mengenai pemahaman tentang pengolahan limbah kain kepada para pekerja.

Berikut hasil persentase mengenai pemahaman pengolahan limbah konveksi setelah diadakan sosialisasi kepada pekerja:

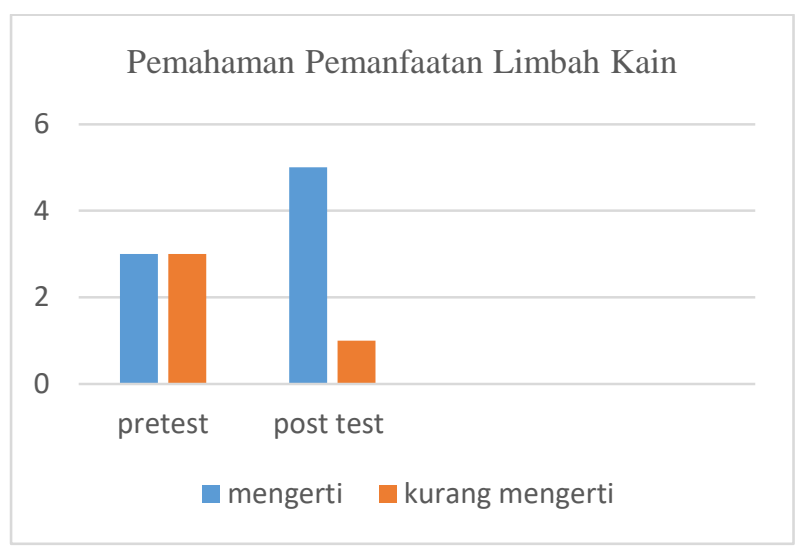

Diagram 1. Pemahaman Pemanfaatan Limbah Kain

Hasil dari pretest adalah kurangnya pengetahuan para pekerja Malika Tailor dalam hal pengelolaan limbah kain perca, sehingga yang dilakukan selama ini adalah dibuang begitu saja. Kemudian, dengan adanya kegiatan pendampingan ini para pekerja sudah mulai mengerti tentang pengelolaan limbah kain perca dari Malika Tailor.

Sesuai dengan hasil pretest dan post-test dia atas.

Sekarang para pekerja sudah mampu memahami bagaimana seharusnya limbah kain diolah untuk menjadi sesuatu yang bernilai ekonomis.
Limbah kain yang sebelumnya ditelantarkan ataupun dibuang kini dapat diolah kembali menjadi barang yang dapat digunakan bahkan memiliki nilai. Adapun yang telah kami lakukan adalah sosialisasi cara pembuatan barang yang bisa diolah dari limbah kain. Selain pelaksanaan sosialisasi, kami juga membuat poster tentang pentingnya pengolahan limbah kain. Poster tersebut telah dibuat dan dipasang di tempat mitra. Poster tersebut berisikan tata cara pembuatan barang dari limbah kain. Adapun barang yang dapat diolah dengan menggunakan limbah kain adalah, ikat rambut, connector masker, dan juga pot bunga.

Kegiatan ini tidak lepas dari kontribusi para pekerja dalam pelaksanaan kegiatan kami. Hanya saja, pekerja mitra tidak sepenuhnya berkontribusi dalam pembuatan barang hasil olahan limbah kain. Hal ini dikarenakan, para pekerja yang mengejar target kerja tetap mereka yang harus segera diselesaikan yaitu pembuatan seragam mahasiswi.

Kegiatan ini berhasil diselenggarakan dengan optimal. Dengan segala keterbatasannya, pelaksana kegiatan mampu menyelesaikan permasalahan yang ada. Hasil dari pendampingan ini juga nantinya dapat diteruskan dan dilaksanakan secara berkelanjutan. Sehingga, para pekerja nantinya dapat terbantu dengan kegiatan pengabdian kepada masyarakat ini. Hasil dari kegiatan ini sangat bermanfaat, terutama bagi mereka para pekerja Tailor Malika. 
564 Pendampingan Pengolahan Limbah Konveksi Di Malika Tailor UNIDA Putri - Dwi Ardiyanti, Inda Aini Sichah, Alfidayati Hasna, Cindy Oktaviana Putri, Nurmalasari Mulia Putri, Adinda Muhariani DOI: https://doi.org/10.31004/abdidas.v2i3.315

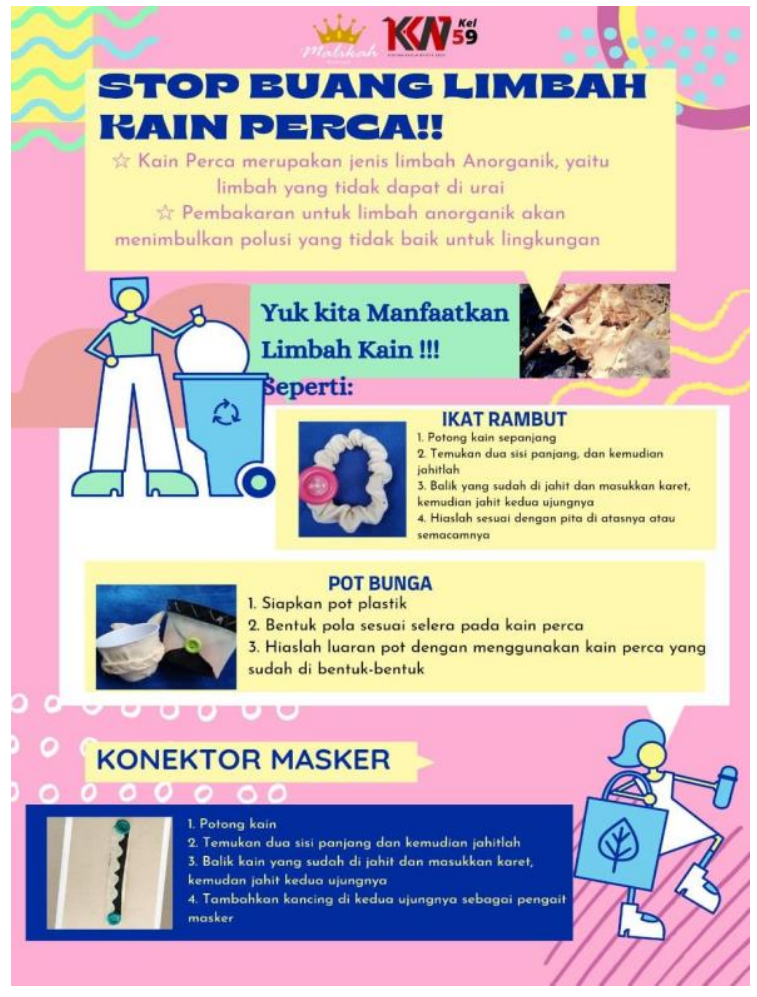

Gambar 1. Poster Sosialisasi Program

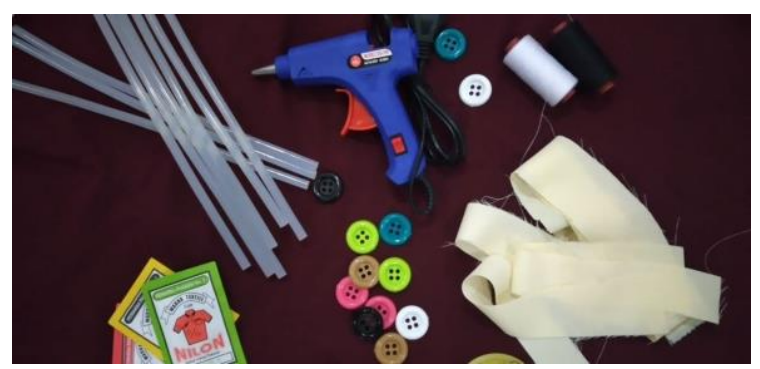

Gambar 2. Bahan yang Diperlukan untuk Pengolahan Limbah Kain Perca

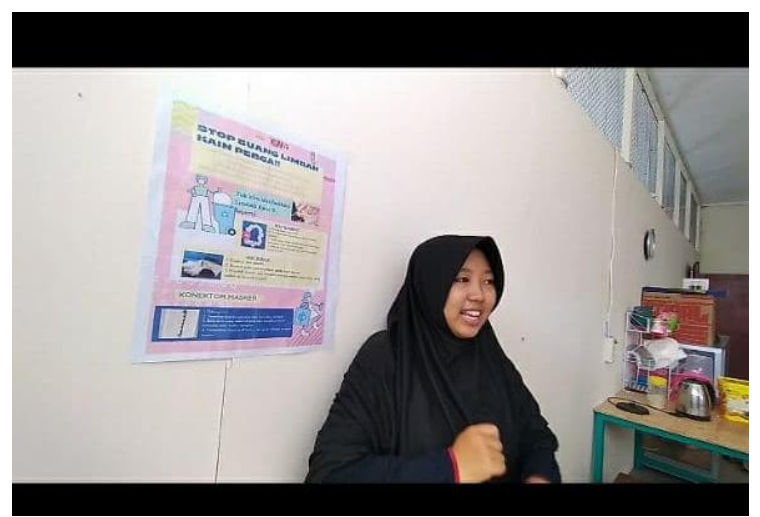

Gambar 3. Pelaksanaan Sosialisasi Program

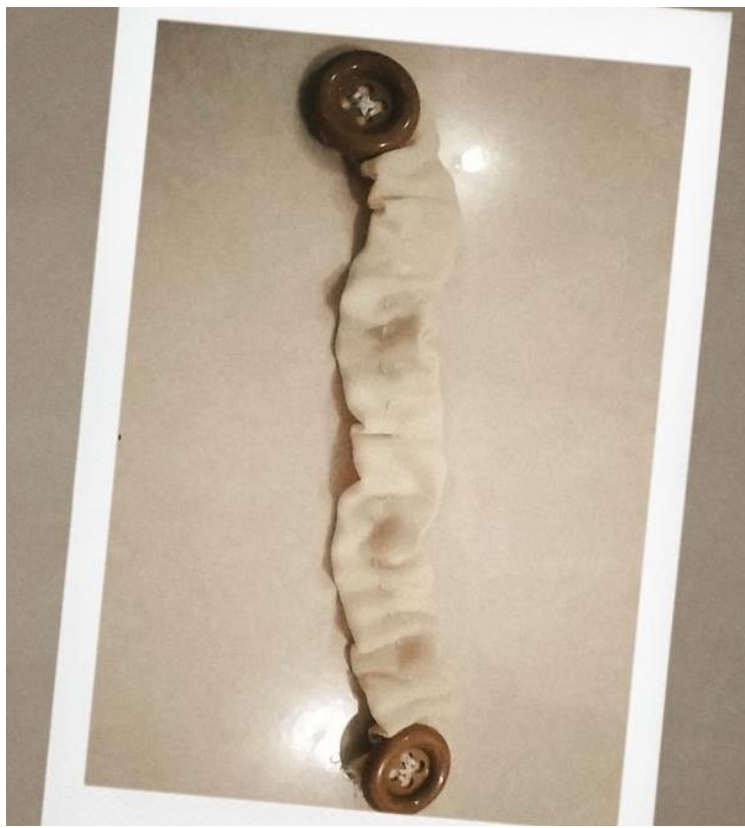

Gambar 4. Hasil Konektor Masker

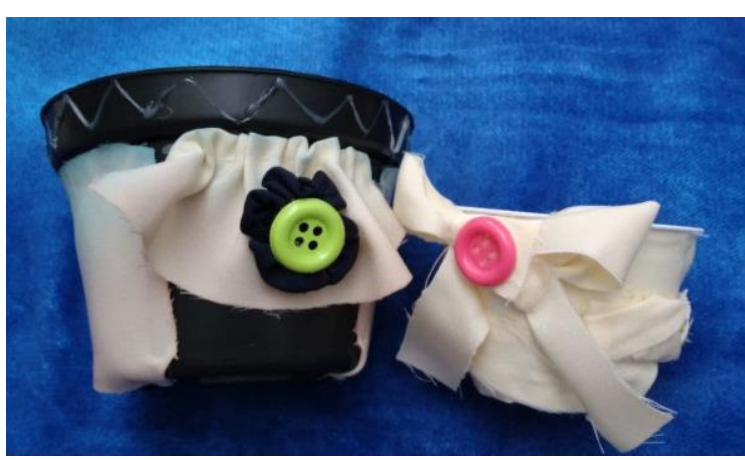

Gambar 5. Hiasan Pot Bunga

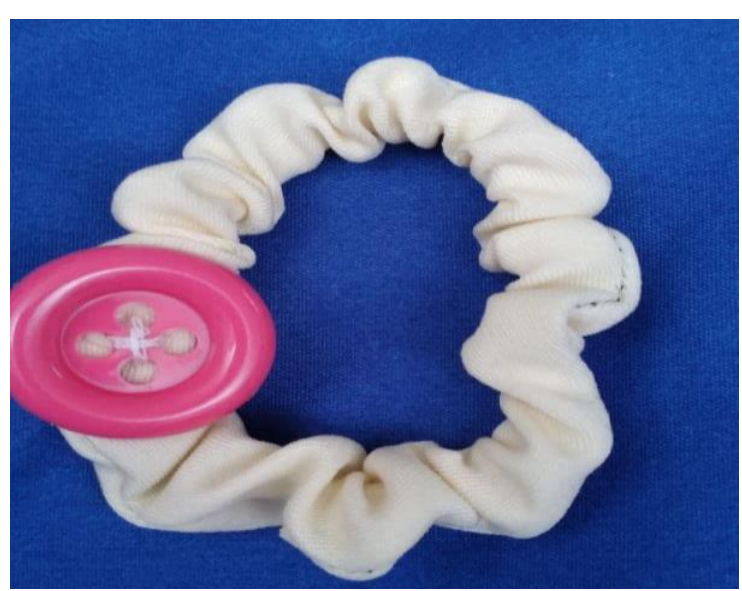

Gambar 6. Ikat Rambut 
565 Pendampingan Pengolahan Limbah Konveksi Di Malika Tailor UNIDA Putri - Dwi Ardiyanti, Inda Aini Sichah, Alfidayati Hasna, Cindy Oktaviana Putri, Nurmalasari Mulia Putri, Adinda Muhariani

DOI: https://doi.org/10.31004/abdidas.v2i3.315

\section{SIMPULAN}

Dari kegiatan pendampingan terhadap pekerja Tailor UNIDA Putri Regular mengenai pemanfaatan limbah kain dapat disimpulkan bahwa:

1. Setelah diadakan sosialisasi mengenai pemanfaatan limbah kain menjadi barang yang memiliki nilai ekonomis yang tinggi, tingkat pemahaman pekerja Tailor UNIDA Putri meningkat,

2. Para pekerja mengetahui dan memahami akibat dari limbah kain yang dibiarkan saja tanpa diolah kembali.

3. Para pekerja memahami pentingnya memanfaatkan limbah kain menjadi barang yang memiliki nilai ekonomis tinggi dapat menambah penghasilan bagi mereka.

\section{UCAPAN TERIMA KASIH:}

Terima kasih atas segala bantuan dan dukungan dari berbagai pihak, di antaranya:

1. Allah SWT yang telah memberi kesempatan dan umur hingga kegiatan ini dapat terlaksana dengan baik.

2. UNIDA Gontor yang memberikan berbagai dukungan material dan kesigapannya untuk merespon terkait KKN Tematik UNIDA 2021.

3. Mahasiswa sebagai tonggak dari kegiatan ini yang melimpahkan ide dan tenaganya untuk keberlangsungan kegiatan ini agar dapat dicapai dengan optimal.

4. Malika Tailor yang sudah berkenan bekerjasama dan berparitipasi dalam menyelenggarakan kegiatan pengabdian kepada masyarakat ini dengan baik.

\section{DAFTAR PUSTAKA}

Ekström, K. M., \& Salomonson, N. (2014). Reuse and Recycling of Clothing and Textiles-A Network Approach. Journal of Macromarketing, 34(3), 383-399. https://doi.org/10.1177/0276146714529658

Hawley, J. M. (2006). Textile recycling: A system perspective. Recycling in Textiles: A Volume in Woodhead Publishing Series in Textiles, March 2006, 7-24. https://doi.org/10.1533/9781845691424.1.7

Purwasih, R., Anita, I. W., \& Afrilianto, M. (2020). Pemanfaatan Limbah Kain Perca untuk Mengembangkan Media Pembelajaran Matematika bagi Guru SD PENDAHULUAN Sampah yang bahan dasarnya sintesis seperti plastic dan kain sulit terurai . Sampah yang tidak dapat terurai oleh alam menimbulkan dampak yang negatif. Jurnal SOLMA, 09(1), 167-175.

Sandin, G., \& Peters, G. M. (2018). Environmental impact of textile reuse and recycling - A review. Journal of Cleaner Production, 184, 353-365. https://doi.org/10.1016/j.jclepro.2018.02.266

Susilo, R., \& Karya, A. (2012). Pemanfaatan limbah kain perca untuk pembuatan furnitur. Jurnal Tingkat Sarjana Senirupa Dan Desain No.1, 3(1), 1-6. 